\title{
Accord could lift block on European biotech patents
}

[MUNICH] The prospects for a clarification of Europe's rules on the patenting of transgenic animals and plants brightened last week when the European Parliament's legal affairs committee approved - with amendments - a revised directive drawn up by the European Commission in Brussels.

The way is now paved for approval of the directive - which covers biotechnological inventions and allows the patenting of human genes, as well as of transgenic animals and plants - in the parliament's plenary session next month. An earlier draft directive was rejected by the parliament two years ago (see Nature 374, 103; 1995).

Approval is expected despite a vociferous minority of members of the parliament, particularly those representing 'green' parties, who oppose the patenting of life on moral grounds. Others argue that the draft directive is important because it clarifies the European Patent Convention, the book of rules for the European Patent Office (EPO) which was drawn up before the advent of genetic engineering.

The convention explicitly excludes from patentability animal and plant 'varieties' in order to protect plant breeders' rights although animals and plants are patentable. This ambiguity has led to a two-year halt by the EPO in the issuing of patents relating to animals and plants that are the products of biotechnological inventions.

In 1995 an EPO board of appeals ruled against the issuing of a patent covering a procedure producing herbicide-resistant plants and the plants and seeds arising from the process to the Belgian company Plant Genetics Systems. The board argued that a transgenic plant represents a collection of plant varieties (see Nature 381, 178; 1996).

In consequence, the EPO has had to put on hold more than 1,100 applications for patents covering plants, and nearly 500 patents covering animals, until the law is clarified. It has put on hold any ruling in the appeal against its most high-profile animal patent application, the Harvard oncomouse.

The new wording in the draft directive, as amended by the legal affairs committee, states that "inventions which concern plants or animals may be patented if the practicability of the invention is not technically confined to a particular plant or animal variety".

This wording clearly distinguishes species and varieties, says Christian Guggerell, an expert on biotechological inventions at the EPO. If used as a guide by the $\mathrm{EPO}$, even though it is independent of the commission, it would allow the backlog of applications to be processed, he believes.

But first the EPO requires new case law of its own. The next case to be considered by an EPO board of appeals will probably concern an application brought by the company CibaGeigy now part of Novartis.

The board of appeals, which could rule as early as next autumn, could refer to the more precise wording on plants and plant varieties in the commission's draft directive to help it to interpret its own more imprecisely written rules.

Alison Abbott

\section{Leicester centre is set for take-off}

[LONDON] A UK National Space Science Centre (right) should lift off in Leicester in 2000 with the aim of attracting 300,000

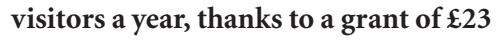
million (US\$38 million) from the Millennium Commission.

The centre will include displays and hands-on activities to convey current knowledge about space, astronomy and the global environment. There will be a planetarium and a Challenger Learning Centre - an educational initiative backed by the US space agency NASA — offering simulated space flights.

Exhibits will include objects from the European Space Agency and pieces of moon rock from NASA.

The centre will be built on the site of a decaying sewage treatment works which is owned by Leicester City Council and Severn Trent Water.

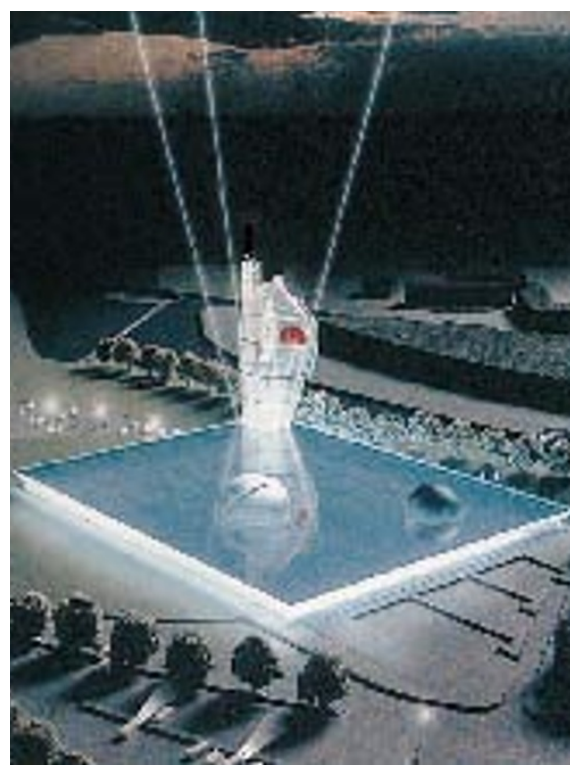

\section{Japan reaches a compromise on organ transplants}

[TОКYO] Long-awaited legislation designed to provide a legal framework for organ transplants has at last been passed by Japan's parliament, the Diet. But only after a bizarre compromise was reached on the legal definition of death.

For more than a decade, Japan's medical policy-makers have been trying to gain public acceptance of "brain death" as death of an individual, so that organs such as the liver and heart can be removed from brain-dead patients for use in transplants (see Nature $318,591 ; 1985)$. Japan's first heart transplant in 1968 led to demands that the doctor responsible be tried for murder. No heart transplants have been carried out since.

The legislation that passed the Diet last week is a modification of an earlier bill passed by the Diet's lower house in April which allows organs for transplantation to be removed from "brain death bodies" (see Nature 387,$5 ; 1997)$. But the original bill met strong opposition in the upper house, where many legislators were unwilling to recognize brain death as death.

In the compromise legislation, braindead patients are recognized as being dead only if they have given prior written permission for donation of their organs. Otherwise, their heart must stop beating before they are considered to be dead.

Futhermore, as in the original bill, the family of the deceased must give permission for a transplant to be carried out, and the family's wishes will override those of the brain-dead patient.

There are various explanations as to why the Japanese are so opposed to accepting brain death and organ transplants. These include a strong belief that the body and soul are inseparable and a Confucian concept that the body is a gift of one's parents that cannot be given away. Nevertheless, this has not stopped many Japanese from seeking transplants overseas, even in underdeveloped countries such as the Philippines.

The legislation, while opening the door to transplants, is unlikely to lead to widespread organ transplantation, commentators say. Quite apart from an unwillingness to recognize brain death, Japanese people generally are unwilling to donate their organs. Evidence for this can be seen in the fact that kidney transplants, which can be carried out after the heart has stopped beating, are uncommon.

There is also no well-established system of donor cards in Japan. Furthermore, as donors must give prior written consent to the use of their organs, none will become available for children.

DavidSwinbanks 